\section{Facilities management and planning for heritage sites: lessons learnt from a pilot study on disused military sites}

\author{
Lawrence Wai-chung Lai and \\ Daniel Chi-wing $\mathrm{Ho}$
}

\section{The authors}

Lawrence Wai-chung Lai is a Reader and Daniel Chi-wing Ho is an Associate Professor, both in the Department of Real Estate and Construction, University of Hong Kong, China.

\section{Keywords}

Facilities management, Stakeholders,

Environmental audit, Surveys, Conservation, Hong Kong

\section{Abstract}

This short paper presents the lessons learnt for conservation planning of heritage sites from a pilot study on disused military structures on Devil's Peak, Hong Kong. Stakeholders' interest and surveying as facilities management factors should be well considered in the planning stage for heritage conservation. Thus, public education and involvement and on-site land surveying is essential for future project success.

\section{Electronic access}

The Emerald Research Register for this journal is available at

http://www.emeraldinsight.com/researchregister

The current issue and full text archive of this journal is available at

http://www.emeraldinsight.com/0263-2772.htm

\section{Facilities}

Volume $21 \cdot$ Number $3 / 4 \cdot 2003 \cdot$ pp. 80-88

C MCB UP Limited · ISSN 0263-2772

DO। $10.1108 / 02632770310469398$

\section{Introduction}

While the designation of a heritage site and allocation of public funding for its research may well be political decisions, the actual conservation planning and facilities management of the site is a professional matter. This short paper serves the purpose of discussing some important facilities management considerations for conservation planning. According to the British Institute of Facilities Management (BIFM):

... facilities management" means "the practice of co-ordinating the physical workplace with the people and work of an organisation (Atkin and Brooks, 2000, p. 3).

While the meaning of "facilities management" in this paper is broader, encompassing recreation place and leisure activities, the very concept of "co-ordination" in the BIFM definition is retained. The notion of co-ordination underlies the strategic concepts of "estimates" in and "psychology" ascribed to Sun Tzu's The Art of War (Griffith, 1963), which is of particular interest in the context of our paper on military matters.

\section{The political and research background}

Hong Kong and Macau were both colonies of old European sea powers. Thus, it is natural that both areas have a rich heritage of Western coastal defence structures (Davies, 1985, Graca 1984) in additional to any indigenous Chinese defence infrastructure (Siu, 1997). However, the attitude of the British and Portuguese colonial regimes, that governed Hong Kong and Macau, respectively, regarding coastal defence structures, varied significantly. As a consequence, the Macau forts often share strategically located high grounds with seminaries, cathedrals, churches, reflecting the religious aspirations of the colonial power. Before its return to China, these forts and churches were systematically restored to their former glory and have become tourism assets. The classic example is the Monte Fortress of St Paul (Project Team of the Museum of Macau 1999), for which an application for designation as a world heritage site has recently been filed.

The authors are grateful to the Lord Wilson Heritage Trust for financial support for conducting the land surveying exercise. They are also indebted to two anonymous referees for their useful advice. 
The more modern Hong Kong forts occupy much higher and precipitous hilltops in the urban fringe and countryside. There is no church or chapel that is open to the public on these hills or inside the military areas. Unlike Macau, which has escaped any major war, Hong Kong was a battlefield in the Second World War and the batteries in Hong Kong were actively engaging Japanese invaders in an effective defensive battle (Lai, 2001). Yet, in spite of their historic value and the fact that many of them are inside country parks (Thrower, 1984), the batteries are seldom converted for public recreation purposes. Most are relegated to a functional use, the siting of wireless communications installations

(Plate 1). That such sites, as restricted areas of public utility companies or barracks of the military, may protect the war relics therein is purely coincidental. The exception is the Pinewood Battery site[1], which has become a park managed by government. Others are left to waste. The Devil's Peak is a case in point. The de-colonisation process does not generate any systematic government attempt to rehabilitate war relics. Bunkers and pillboxes in country parks are often thoughtlessly destroyed to make room for new buildings or subject to lavish cement spraying for slope stabilisation. The fact is that the British colonial administration that returned to Hong Kong after the surrender of Japan, kept a very low profile about the hostility and occupation. However, in spite of official apathy, visitors and residents of Hong Kong have been rapidly building up a literature on the British military structures. Some examples, in chronological order of publications, are Rollo (1992); Siu (1995); Ko and Wordie (1996); Horsnell (2000a, b); Ko (2001); and Lai et al.

Plate $1 \mathrm{~A}$ gun emplacement at Bokhara Battery, Cape d'Aguilar, being used for accommodating facilities as a wireless station

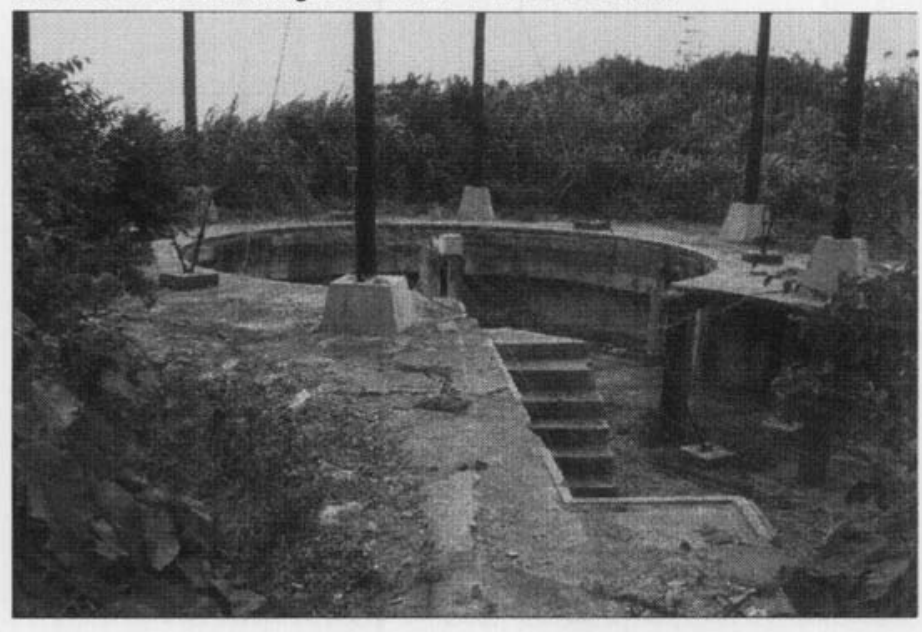

(2001). The attention of the public has been alerted and there has been a growing interest in media coverage of war relics (Eastern District Star, 2002; Lee, 2002; South China Morning Post, 2002). This is, though, a dedicated work to military installations about Hong Kong in such details as those documented in Spiteri (1994, 1996) for Malta and Harris (1997) for Bermuda, is yet to be written. It is within this context that this paper is written.

\section{The Devil's Peak as a heritage site}

Hong Kong was one of the most significant naval and trading bases of the British Empire. With a deep and well-sheltered natural harbour, Victoria Harbour, colonial Hong Kong, had five dockyards that could service war ships. The only eastern marine approach to Victoria Harbour is Lei Yue Mun Pass. It has a depth of more than $22 \mathrm{~m}$. and is extremely narrow. In the age of the battleship, the British military authority built a number of batteries on the highlands on both sides of this vital gateway to Victoria Harbour. Devil's Peak is on the northern side of the Pass. With the shape of the cone of a volcano and defining the easternmost end of the Kowloon Range, the Devil's Peak had, before its conversion into a British stronghold, a much longer military history. According to Siu (1994), before the development of the Victoria City, the coastal area of Devil's Peak was once occupied by seafaring and Taiwanbased Ming royalist forces that stubbornly resisted Manchu invaders.

At the foothill of Devil's Peak there is now a shanty town, the Lei Yue Mun squatter village, famous to tourists for live coral fish restaurants and $a$ mother of the sea goddess temple, the Tin Hau Temple. Today, there is little visible trace of the Ming military presence on Devil's Peak. The ambitious plan of the British War Department to convert Yau Tong in the vicinity into a major barracks has never materialised. Yet, the disused British military structures on the Devil's Peak are still in a fairly good condition for tourists and those interested in the history of the two world wars.

Built between 1900 and 1914, the major parts of the military sites on Devil's Peak are intact in spite of wartime destruction and post-war neglect. Unlike most other Second World War ruins or installations in Hong Kong, such as those on the Stonecutters 
Island, on Mount Davies, in Stanley Fort, or at Cape d'Aguilar, these sites on Devil's Peak are not only conspicuous but also open-access and are within short walking distance from major population areas and public transport nodes. The views of Victoria Harbour and beyond on Devil's Peak, now a tranquil enclave after the relocation of the airport from Kai Tak, are superb (Plate 2).

The four main clusters of military structures on Devil's Peak that have survived (Figure 1):

(1) The Devil's Peak Redoubt, that stands on the summit at a level of $222 \mathrm{~m}$. (Figure 2). With the size of about three basketball courts and built in 1914[2], this redoubt is a machine stronghold with a contiguous loop-holed firing wall, built partly of stones and partly cement. Encircling the summit of Devil's Peak, it provided fire cover for the military installations below. In addition, it also served as the Fire Command East for the artillery of colonial Hong Kong.

(2) A small site at $196 \mathrm{~m}$., which is connected with the redoubt uphill by a dugout and was likely the site for an observation post and formed at the same time the redoubt was built.

(3) Gough Battery, at about $160 \mathrm{~m}$. and built before 1900, with one 9.2in. gun emplacement and one 6in. quick-firing gun emplacement. The profile of both emplacements is largely intact (Figure 3).

(4) Pottinger Battery, at about $80 \mathrm{~m}$. and built at about the same time as Gough Battery, with two 9.2-inch gun emplacements. Just one of the emplacements has escaped the fate of being buried by filling in the 1970 s.

Plate 2 The view of eastem Victoria Harbour, as seen from the cut platform on Devil's Peak, below Gough Battery

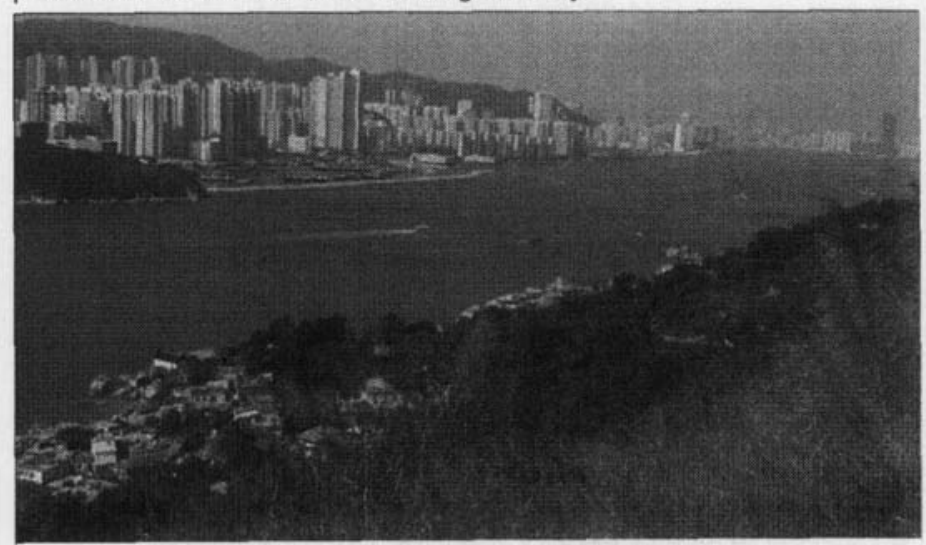

Note: The headland across the strait (Lei Yue Mun Pass) in the middle ground is the site of Lei Yue Mun Fort. Mount Parker and Mount Butler are in the background

\section{The survey}

The authors have conducted initial building inspections, aerial photo analysis and archive research on the key surviving building structures on the sites since March 2000. With financial support of the Lord Wilson Heritage Trust since March 2002, they have also obtained the assistance of a local land surveying firm in carrying out a land survey of these buildings to a scale of $1: 1,000$ with a view to not only update the $1: 1,000$ government survey plans and provide a basis of heritage conservation proposals, but also to find out "as built" information to compare with that shown on the original drawings produced by the British military planners. The Public Record Office, in Hong Kong, has a collection of records of military sites on Devil's Peak in relation to the original plans for the redoubt, the location plan of three battery sites (one of which has become the redoubt); the section plans for Gough and Pottinger Batteries. These records, while of historical interest in themselves, are not complete or of insufficient details for conservation planning, not to mention the fact that the actual construction of the structures did not always faithfully follow the original design[3]. The land surveying exercise commenced in June 2002 and was complete in November 2002.

\section{Lessons learnt}

In the course of our study, we appreciate three lessons about facilities management that are critical in conservation planning. The first couple of lessons relate to stakeholders' interest, which is a well-recognised aspect of facilities management (Atkin and Brooks, 2000; Burnham, 1994). We are in entire agreement with Atkin and Brooks (2000, p. 75) that stakeholders should be involved "as far as practicable" and their input needs to be controlled. The last lesson reflects importance of surveying in planning in terms of stakeholder's interest.

Facilities management factors should be well-considered in conservation planning The major facilities management problem for the military ruins is the open access nature of their environment. Where they are in the vicinity of major population centres, as in the 
Figure 1 Major defence structures on Devil's Peak and its environment

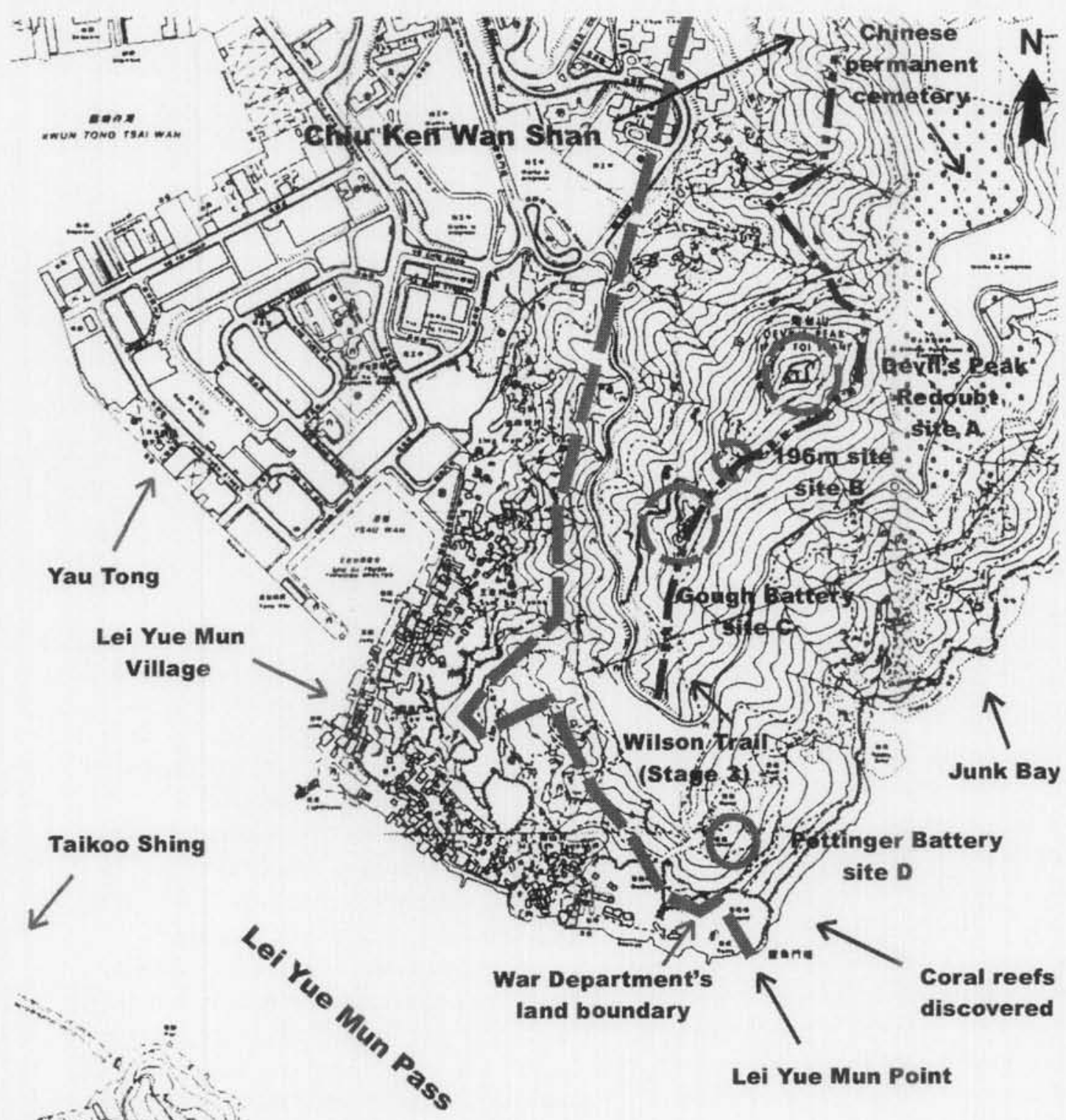

Lei Yue Mun Fort

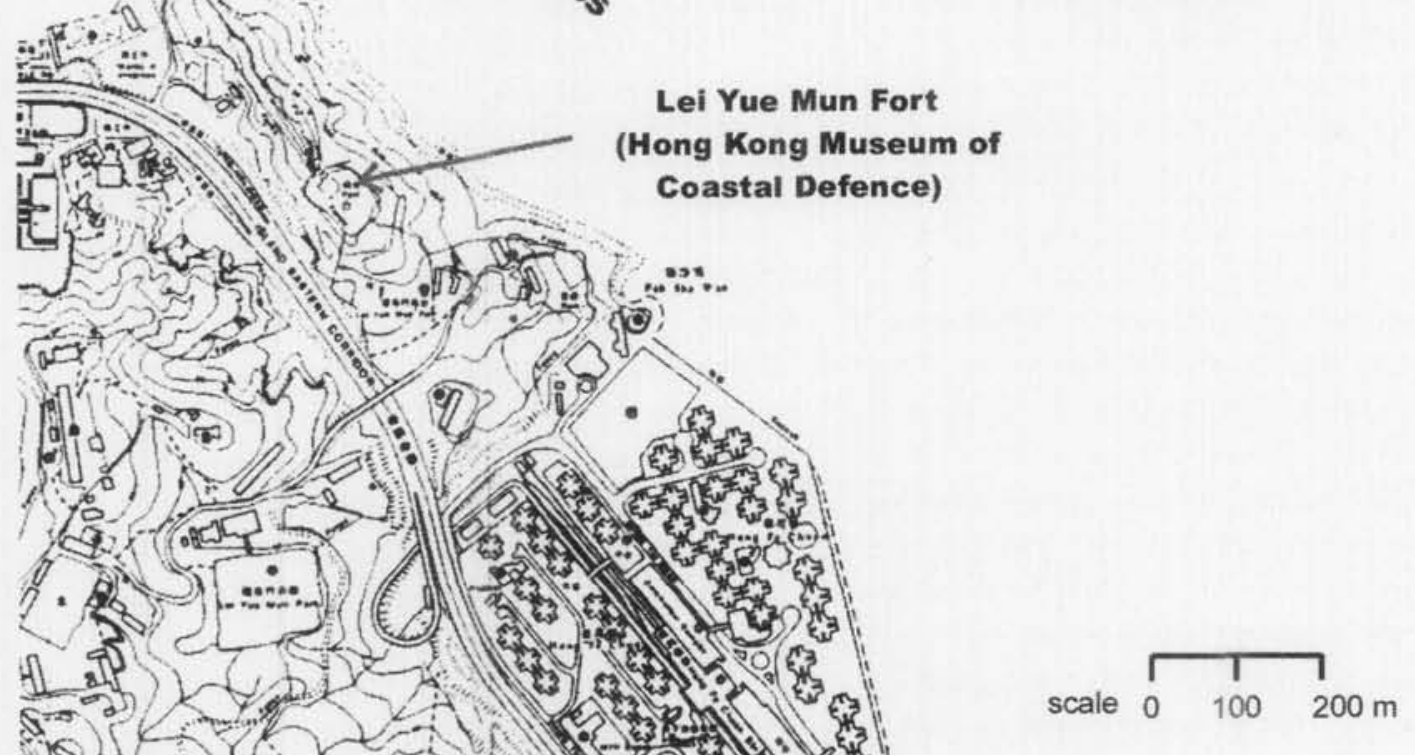




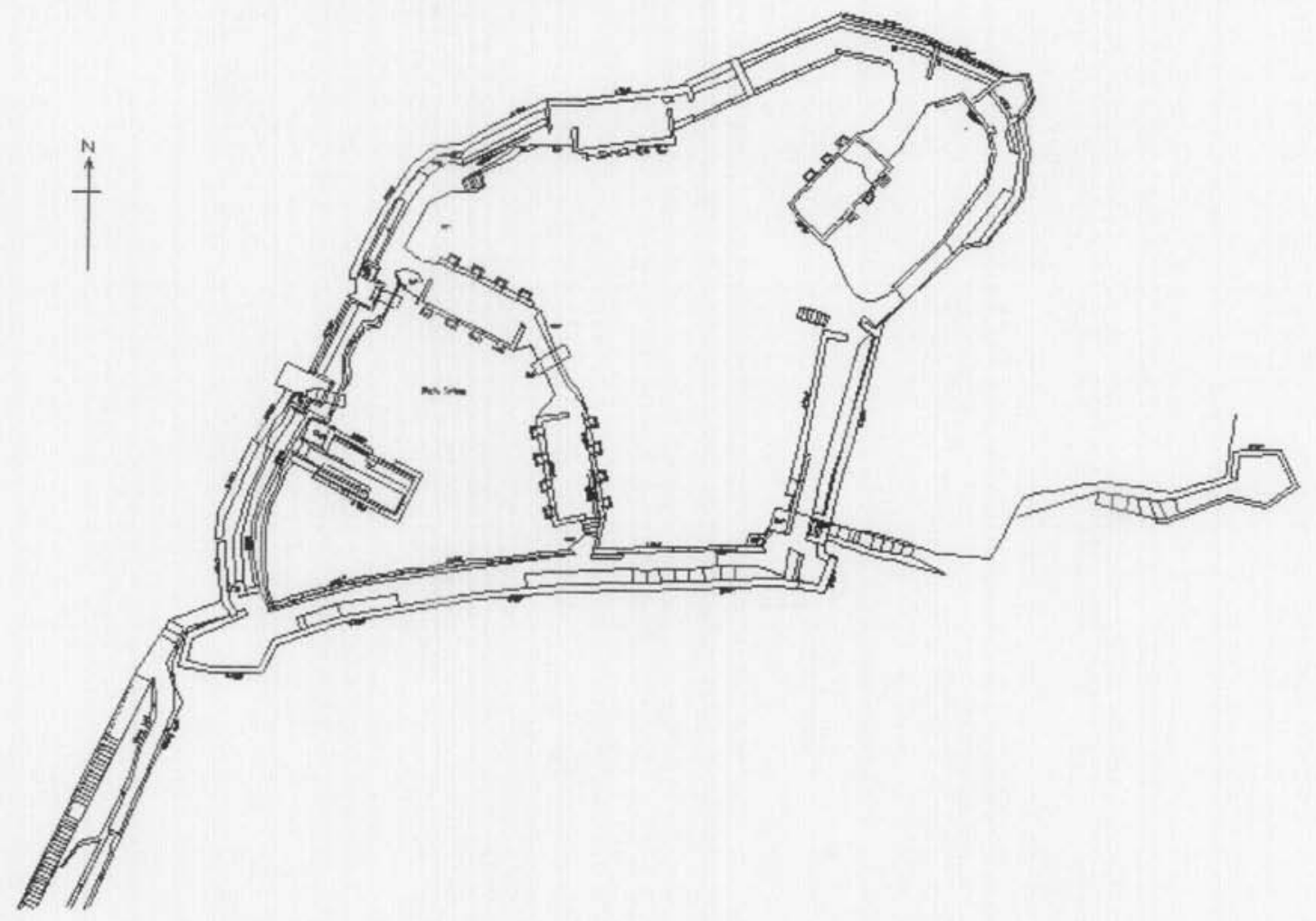

case of our study area, the management problem of access restrictions would be a challenge. However, the locations in a site subject to human disturbance under open access, if carefully mapped out, can reveal to the planner the most attractive elements of the ruins to the general public, the ultimate stakeholders of the area. These elements are typically vantage points, locations where eating and cooking are convenient and comfortable and where views are attractive because of the exposure, shape and forms of the sites and buildings thereon. To experts in military architecture and operations, however, the attractiveness of the site may lie elsewhere. An old path or a retaining wall of little interest to the ordinary member of the public may be the object of intense interest to them.

Thus, in planning for the conservation and use of sites that attract visitors, passive designation of the sites as a heritage site or a "green belt" against development is insufficient and open access is not a good idea if they are of heritage value. To avoid the problems of "rent dissipation" for resources under public domain (Barzel, 1997; Webster and Lai, 2003), access must be somehow restricted. However, the mere use of physical barriers alone is a "hard" solution that is easily breached by adventurous individuals. To convert the area into a completely enclosed or privatised area and the levy of a user charge is a popular option. Less restrictive measures, such as the conversion of the area into a country park with wardens that patrol the area, are preferred if the use is not always intensive. In any event, means to focus attention to the popularly attractive parts of the ruins as well as to more specific aspects of the ruins are essential. Thus, within areas subject to access control, good signage design is a prime consideration.

Safety is also a key issue, especially for extensive areas that are susceptible to hill fires, rain storms, flooding and soil erosion. While access restriction and signage may prevent accidents, a system of emergency evacuation and shelters is essential, even though the popularity of mobile phones has reduced significantly the risks and fear of being trapped by such hazards as hill fires or landslides.

\section{Public education and involvement of stakeholders is essential for successful facilities management}

Access restriction mentioned above should not be confused with the suppression of visitor numbers. It can be observed in public 

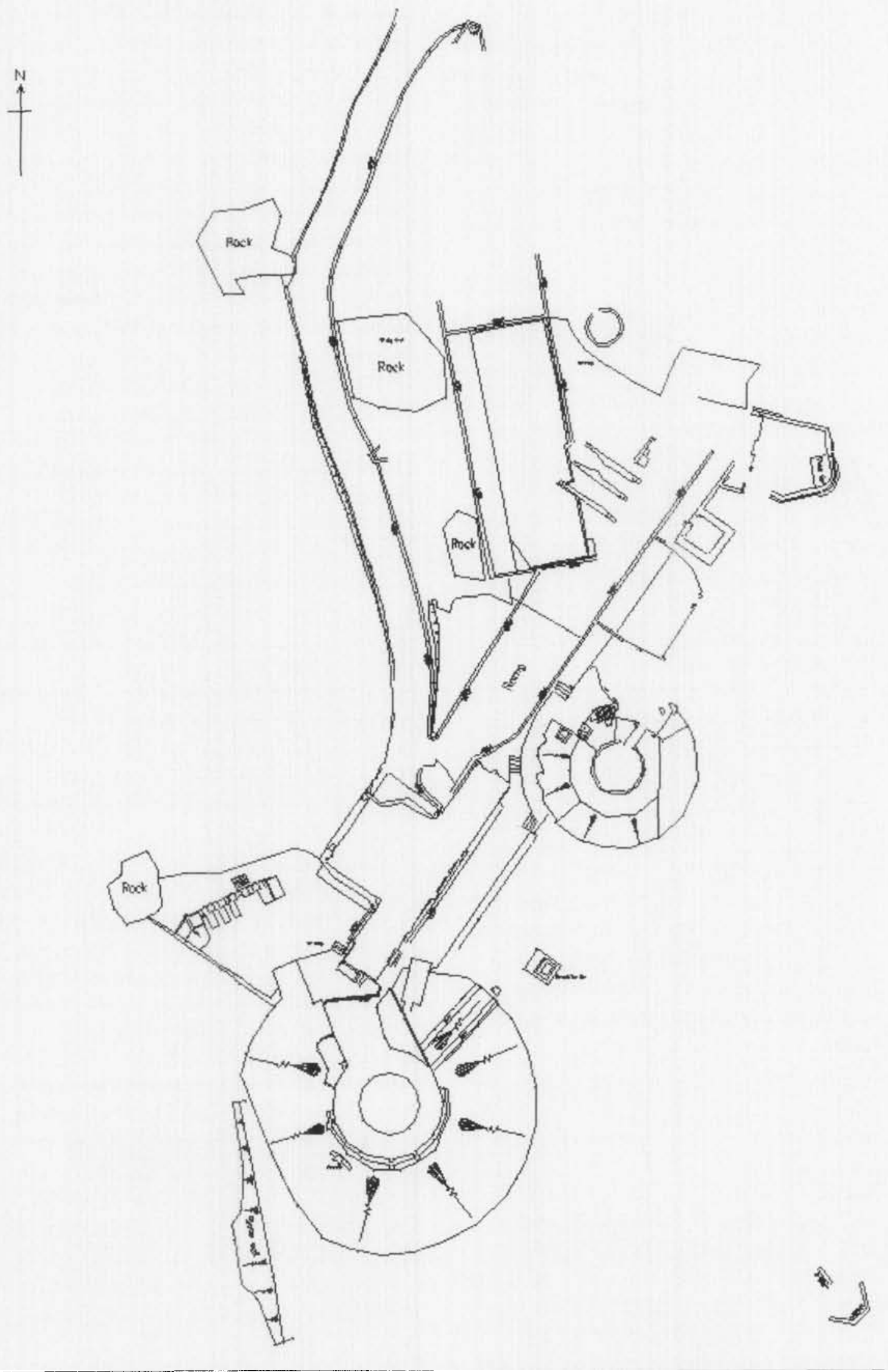

parks in densely populated Hong Kong that the better the level of facilities management, the better behaved are members of the public. The heavily visited Hong Kong Park, for instance, is a good example of good facilities management. The orderly behaviour of visitors is not always as anticipated in small and poorly designed street corner and 
architectural hostile "local open space" which attract drug addicts and tramps. In these small open space pockets, the design is challenging. However, devices to restrict behaviour in this situation, such as partitions in benches to prevent visitors from sleeping on them, are so oppressive that their patrons tend to behave anti-socially.

In our study area, there are a few facts that the conservation planner must take into account. One fact is the stubborn and determined behaviour of morning hikers to develop their private gardens on government land, against government warnings that this is unauthorised. These individuals are also stakeholders of the area. They have developed all sorts of informal devices to store rain and stream water for irrigating fruit trees and flowering plants (Plate 3 ). They have destroyed war relics either deliberately or unintentionally. Their installations are unsightly but their produce does add some excitement to the area.

The other fact is the determination of some members of the public to hoist the national flag on key days in a year. They have indeed erected two pennant stands near the trig station on the summit of Devil's Peak inside the redoubt. There is a code about the location and hoisting of flags and irregular hoisting and display of flags by private individuals in government land is not a regular behaviour. The main issue, however, is that these structures are not erected with regard to the structural integrity of the firing wall of the redoubt and they should have been built properly on the central rock mass of the hilltop.

Plate 3 Improvised steel water tanks, water pipes and a shed found in one of the bunkers inside the Devil's Peak Redoubt

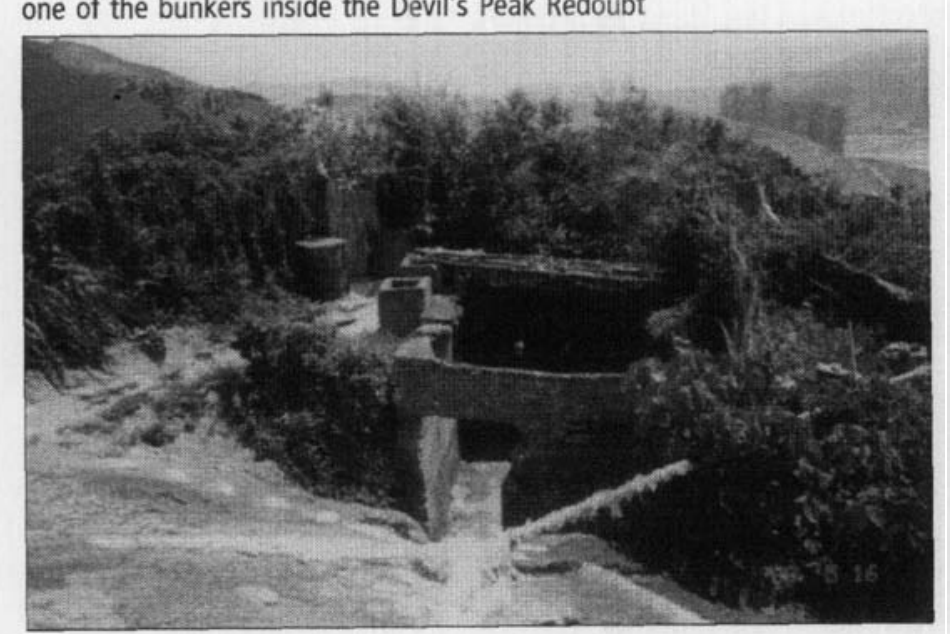

In the light of these two facts, the challenge to the planner is how the creative energy of the gardeners, as well as political sentiment behind the erection of the flag holders, can be channelled so that conservation of relics and cultivation can peacefully coexist and complement each other. If these facts are ignored in planning and design, unhappy confrontation between the access controller and some segments of the public may occur.

Like signage, discussed earlier, the issues identified here for facility management of heritage pertain to a wide array of research arena. They include resource economics and environmental psychology (Fisher et al., 1984; Gardner and Stern 1996; Jones and Uzzell 1996; Gifford 1997).

\section{On-site land surveying is essential to better interpret historical records}

It is desirable in military relic conservation by restoration, that the integrity and wholeness of the original architecture be retained as much as possible. Expertise is required. Without adequate knowledge or interest in details, objects that appear to be of minor importance can be of great value. The stone inscription of "40th Coy REN 1914" [4] inside the Devil's Redoubt (Plate 4), for instance, is not a highly conspicuous object and may easily be removed or covered by cement plastering in a reckless "beautification" campaign. This inscription is important for it informs us who was responsible for building the redoubt and the date of its construction. A few feet away is a rock pattern (Plate 5) that looks like a "Celtic cross" (Friar and Ferguson, 1999, Plate 6, p. 172), which may be of relevance in

Plate 4 The stone inscription showing "40th Coy REN 1914", found on one of the interior walls of the Devil's Peak Redoubt

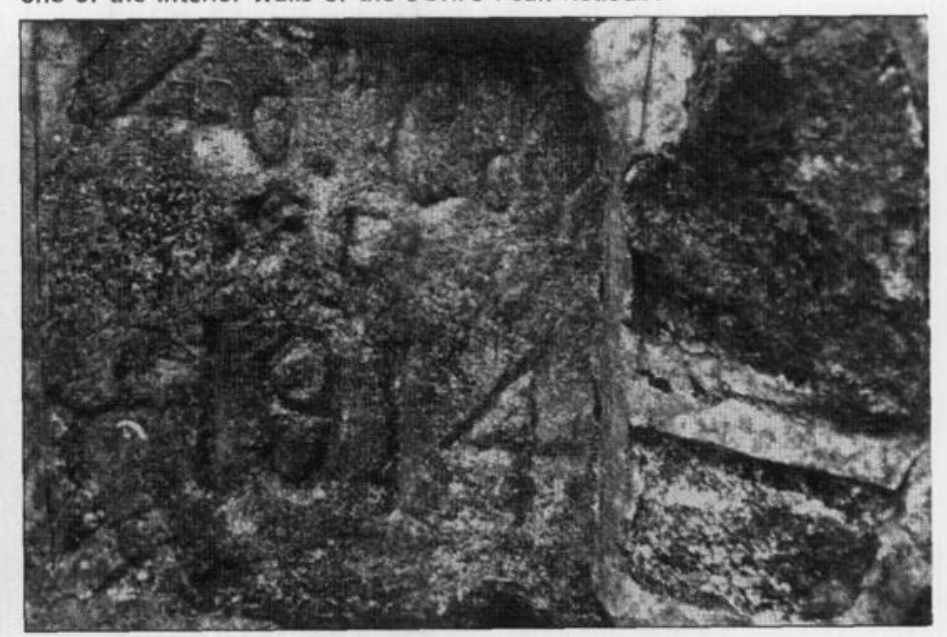


Plate 5 A rock pattern that looks like a "Celtic cross" found inside the Devil's Peak Redoubt

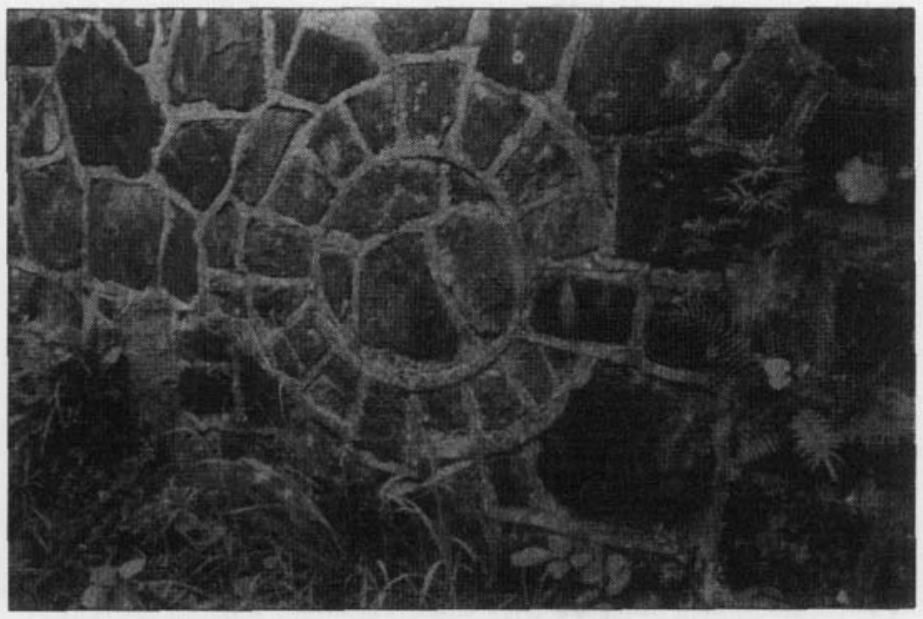

identifying the personnel who built the redoubt

Furthermore, the ordinary maps for picnickers or hikers are generally of a scale too small for conservation planning. In the case of Hong Kong, the largest-scale survey plan was the 1964 series of Crown Land Survey Plans drawn to a scale of 1:600. The modern largest metric scale survey plan is 1:1,000. Many features shown in the imperial series are no longer shown in the 1:1,000 plans. An example is a pillbox at the northwestern end of the Gough Battery. Our study is to produce measured drawings at a scale of $1: 100$ by site surveying, which we consider sufficiently large to initial site conservation planning. However, some features may not be fully, if at all, revealed by viewing aerial photographs or old survey plans alone. Features, which have been concealed by dense overgrowth or camouflage, can only be found out by a meticulous analysis of not only aerial photographs and survey plans produced using techniques of photogrammetry, but also site surveys [5]. In the course of our site inspection and surveys, we have identified a pillbox built of stones laid in the same manner as for the masonry part of the Devil's Peak Redoubt, as well as a tett turret below Gough Battery. None of these can be seen in any previous aerial photograph or survey plan.

\section{Epilogue}

Facilities management is a rapidly developing research and professional area. In this short paper we show how some key considerations in facilities management written large can be useful inputs for conservation planning that respects local involvement and respect the history of military sites. Instead of applying or developing certain management techniques or framework, this paper demonstrates that stakeholders' interest and surveying are facilities management factors that should be well considered in the planning stage for heritage conservation. Public education and involvement and on-site land surveying is argued to be essential for future project success. Though this paper has a modest purpose, it uses terminology from various research disciplines, notably military science, planning, surveying, resource economics and environmental psychology. In so doing, we hope that it would not only kindle an interest in the better protection and management of our common heritage, but also stretch the territory of facilities management by enriching its vocabulary.

\section{Notes}

1 Hong Kong Park, situated in part of the old site of Victoria Barracks, "the Fortress Headquarters" during the Battle of Hong Kong, is not a good example, as the original military structures have been largely removed or "de-militarised" by extensive redecoration.

2 See Note 4, post.

3 Records of military structures can be found in the Royal Artillery Institute at Woolwich and the Public Records Office at Kew Gardens, UK.

4 The meaning is: 40th Company, Royal Engineers, built in 1914 (see Bard, 1988, p. 90).

5 For a survey of literature on the importance of site surveys in aerial photograph interpretation, see Lai (1998), pp. 170-3.

\section{References}

Atkin, B. and Brooks, A. (2000), Total Facilities Management, Adrian Brooks, Blackwell Science, Oxford.

Bard, S. (1988), In Search of the Past: a Guide to the Antiquities of Hong Kong, Urban Council, Hong Kong.

Barzel, Y. (1997), Economic Analysis of Property Rights, 2nd ed., Cambridge University Press, Cambridge.

Burnham, J.M. (1994), Integrative Facilities Management, Inwin Professional Publishing, New York, NY.

Eastern District Star (2002), "Gun mounting found in Sai Wan Battery", p. 16 (Chinese newspaper).

Davies, S. (1985), Chronicles in Stone, Department of Tourism, Macau.

Fisher, J.D., Bell, P.A. and Baum, A. (1984), Environmental Psychology, 2nd ed., CBS College Publishing, New York, NY. 
Friar, S. and Ferguson, J. (1999), Basic Heraldry, Herbert Press, London

Gardner, G.T. and Stern, P.C. (1996), Environmental Problems and Human Behaviour, Allyn \& Bacon, London.

Graca, J. (1984), The Fortifications of Macau, Impresensa Nacional de Macau, Macau.

Griffith, S.B. (1963), Sun Tzu: the Art of War. Oxford University Press, London.

Gifford, R. (1997), Environmental Psychology: Principles and Practice, Allyn \& Bacon, London.

Harris, E.C. (1997), Bermuda Forts: 1612-1957, Bermuda Maritime Museum Press, Bermuda.

Horsnell, R.G. (2000a), "The story of Stanley Fort", The Journal of the Hong Kong Branch of the Royal Asiatic Society, Vol. 38, 1998/1999, pp. 247-63.

Horsnell, R.G. (2000b), "The story of Gun Club Hill Barracks", The Journal of the Hong Kong Branch of the Royal Asiatic Society, Vol. 38, 1998/1999, pp. 265-80.

Jones, E.M. and Uzzell, D.L. (1996), "Meeting the expectations of visitor groups: safety management in theme parks", Ambientals, Vol. 8, p. 85

Ko, T.K. (2001), War Relics in the Green, Cosmos Books, Hong Kong.

Ko, T.K. and Wordie, J. (1996), Ruins of War: a Guide to Hong Kong's Battlefields and Wartime Sites, Joint Publishing (HK) Ltd, Hong Kong.

Lai, L.W.C. (1998), Zoning and Property Rights: a Hong Kong Case Study, Hong Kong University Press, Hong Kong.

Lai, L.W.C. (2001), "The battle of Hong Kong: a note on the literature and effectiveness of the defence", Journal of the Hong Kong Branch of the Royal Asiatic Society, Vol. 39, 1999-2000, pp. 115-36.
Lai, L.W.C., Ho, D.C.W. and Lung, P.Y. (2001), "Disused military structures on Devil's Peak: a post-colonial planning and building analysis on pre-war British coastal defence structures in Hong Kong", EKISTICS

Lee, K. (2002), "War relics disappearing under weight of neglect, historian warns", South China Morning Post, 17 November p. 2.

Project Team of the Museum of Macau (1999), A Museum in a Historic Site: the Monte Fortress of St Paul, Museum of Macau, Macau.

Rollo, D. (1992), The Guns and Gunners of Hong Kong. the Gunners' Roll of Hong Kong, Hong Kong.

Siu, K.K. (1994), The History and Society of Hong Kong, Hong Kong Educational Publishing Co. Ltd, Hong Kong (in Chinese)

Siu, K.K. (1995), "1941: the defence of Hong Kong prior to Japanese invasion", Asian Research, Vol. 16, October, pp. 2-13 (in Chinese).

Siu, K.K. (1997), Forts and Batteries: Coastal Defence in Guangdong during the Ming and Qing Dynasties, Urban Council, Hong Kong.

South China Morning Post (2002), "Pride of place", Opinion, 17 November.

Spiteri, C.S. (1994), Fortresses of the Cross: Hospitaller Military Architecture (1136-1789), Heritage Interpretation Services, Malta.

Spiteri, C.S. (1996), The British Architecture in Malta, Printed Services Ltd, Maita.

Thrower, S.L. (1984), Hong Kong Country Parks, Government Printer, Hong Kong.

Webster, C. and Lai, L.W.C. (2003), Property Rights, Planning and Markets: Managing Spontaneous Cities, Edward Elgar, Aldershot. 